\title{
Relationship between obesity and musculoskeletal disorders: systematic review and meta-analysis
}

\author{
Relação entre obesidade e distúrbios musculloesqueléticos: revisão sistemática e metanálise \\ Relación entre obesidad y trastornos musculoesqueléticos: revisión sistemática y metaanálisis
}

Received: 09/03/2021 | Reviewed: 09/20/2021 | Accept: 10/05/2021| Published: 10/06/2021

Lucas Marques Fortunato

ORCID: https://orcid.org/0000-0001-6704-3126

Universidade Federal do Paraná, Brazil

E-mail: lucasmarquesfortunato@gmail.com

Tatielly Kruk

ORCID: https://orcid.org/0000-0002-7913-3273

Universidade Federal do Paraná, Brazil

E-mail: tatiellykruk@gmail.com

Emilton Lima Júnior

ORCID: https://orcid.org/0000-0002-6887-9387

Universidade Federal do Paraná, Brazil

E-mail: doc.emilton@gmail.com

\begin{abstract}
Introduction: Obesity is considered a public health problem and it is associated with various musculoskeletal disorders, that haven't been reviewed systematically. Therefore, the objective of this study was to describe the relationship between these changes in individuals with obesity. Methods: Lilacs, PubMed, Scielo, Scopus and Web of Science electronic databases were systematically reviewed until July 2018, conducted according to Cochrane guidelines for the development of meta-analysis. Eligibility criteria: inclusion (studies with humans; with a BMI greater than $30 \mathrm{Kg} / \mathrm{m}^{2}$ or above the $85^{\text {th }}$ and $95^{\text {th }}$ percentile for children and adolescents; articles published in Portuguese, English, and Spanish; articles with validated evaluation methods); exclusion (duplicate, non-indexed articles; special populations; meeting summaries, editorials, letters to the editor and reviews). Results: Based on moderate evidence, knee postural changes in patients with obesity were found in two studies $(\mathrm{n}=158)(\mathrm{OR} 14,26$, IC $95 \% 4,98-40,80), \mathrm{I}^{2}=0 \%(\mathrm{p}=0,000)$, foot postural changes were found in 3 studies $(\mathrm{n}=338)(\mathrm{OR} 3,20$, IC 95\% 2,08$4,94), I^{2}=0 \%(p=0,000)$. Two studies were identified for arthritis $(n=1331)(O R 3,38, I C 95 \% 0,72-1582), I^{2}=38,95 \%$ $(\mathrm{p}=0,122)$. Pain was reported in the lower limb and the spine. Four studies were found for the former $(\mathrm{n}=1560)(\mathrm{OR}$ 5,51 IC 95\% 2,07-14,61), $\mathrm{I}^{2}=81,02 \%(\mathrm{p}=0,001)$, and three for the latter $(\mathrm{n}=499)(\mathrm{OR} 9,78$ IC 95\% 2,59-36,93), $\mathrm{I}^{2}=86,58 \%(\mathrm{p}=0,000)$. Conclusion: Results show that obesity has a negative impact on musculoskeletal health, with results statistically significant for knee and foot postural changes, arthritis, and pain in the spine and lower limbs.
\end{abstract}

Keywords: Obesity; Metanalysis; Postural change; Pain; Locomotor system.

\section{Resumo}

Introdução: A obesidade é considerada um problema de saúde pública e está associada a vários distúrbios musculoesqueléticos, e ainda não foram revisados sistematicamente. Sendo assim, o objetivo do estudo foi descrever a relação entre essas alterações em indivíduos com obesidade. Métodos: Lilacs, PubMed, Scielo, Scopus e Web of Science, foram sistemáticamente revisadas até julho de 2018, conduzida pelas diretrizes da Cochrane para o desenvolvimento de metanálise. Critérios de elegibilidade: inclusão (estudo com humanos; com IMC maior que 30 $\mathrm{Kg} / \mathrm{m}^{2}$ ou superior ao percentil 85 e 95 para crianças e adolescentes; artigos publicados na língua portuguesa, inglesa e espanhola; artigos com métodos de avaliação validados); exclusão (artigos duplicados, não indexados; populações especiais; resumos de reuniões, editoriais, cartas ao editor e revisões). Resultados: Com base em evidências moderadas, alterações posturais em joelho em pacientes com obesidade foram encontradas em dois estudos $(\mathrm{n}=158)$ (OR 14,26, IC 95\% 4,98-40,80), $\mathrm{I}^{2}=0 \%(\mathrm{p}=0,000)$, alterações posturais no pé em 3 estudos $(\mathrm{n}=338)(\mathrm{OR} 3,20, \mathrm{IC}$ $95 \%$ 2,08-4,94), $\mathrm{I}^{2}=0 \%(\mathrm{p}=0,000)$. Foram identificados dois estudos para artrite $(\mathrm{n}=1331)(\mathrm{OR} 3,38$, IC 95\% $0,72-$ $1582), I^{2}=38,95 \%(p=0,122)$. A dor foi constatada nos membros inferiores e na coluna vertebral. Nos membros inferiores quatro estudos foram identificados $(n=1560)\left(\mathrm{OR} 5,51\right.$ IC 95\% 2,07-14,61), $\mathrm{I}^{2}=81,02 \%$ ( $\left.\mathrm{p}=0,001\right)$, já na coluna três estudos $(n=499)$ (OR 9,78 IC 95\% 2,59-36,93), $I^{2}=86,58 \%(p=0,000)$. Conclusão: Sendo assim a pesquisa revela que a obesidade tem impacto negativo na saúde musculoesquelética, com resultados significativos estatisticamente para alteração postural em joelho e pé, artrite e dor na coluna vertebral e membros inferiores.

Palavras-chave: Obesidade; Metanálise; Dor; Alteração postural. 


\begin{abstract}
Resumen
Introducción: La obesidad es considerada un problema de salud pública y está asociada a varios trastornos musculoesqueléticos, y no ha sido revisada de manera sistemática.Así, el objetivo del estudio fue describir la relación entre estos cambios en individuos con obesidad.Métodos: Lilacs, PubMed, Scielo, Scopus y Web of Science fueron revisados sistemáticamente hasta julio de 2018, guiados por las guías de Cochrane para el desarrollo de metanálisis.Criterios de elegibilidad: inclusión (estudio con humanos; con IMC mayor a $30 \mathrm{~kg} / \mathrm{m}^{2} \mathrm{o}$ mayor a percentil 85 y 95 para niños y adolescentes; artículos publicados en portugués, inglés y español; artículos con métodos de evaluación validados); exclusión (artículos duplicados, no indexados; población, poblaciones especiales, resúmenes de reuniones, editoriales, cartas al editor y reseñas).Resultados: Basado en evidencia moderada, se encontraron cambios posturales en la rodilla en pacientes obesos en dos estudios $(\mathrm{n}=158)(\mathrm{OR} 14.26$, IC 95\% 4.9840.80), I2 = 0\% ( $\mathrm{p}=0.000)$, cambios posturales en el pie en 3 estudios $(\mathrm{n}=338)(\mathrm{OR} 3,20, \mathrm{IC} 95 \% 2,08-4,94), \mathrm{I} 2=$ $0 \%(\mathrm{p}=0,000)$.Se identificaron estudios para la artritis $(\mathrm{n}=1331)(\mathrm{OR} 3,38$; IC del 95\%: 0,72-1582), I2 = 38,95\% (p $=0,122)$. Se encontraron dolores en las extremidades inferiores y en la columna.En los miembros inferiores, se identificaron cuatro estudios $(\mathrm{n}=1560)(\mathrm{OR} 551$ IC 95\% 2,07-14,61), I2 = 81,02\% $(\mathrm{p}=0,001)$, ya en la columna tres estudios $(\mathrm{n}=499)(\mathrm{OR} 9,78$ IC 95\% 2,59-36,93), I2 = 86,58\% ( $\mathrm{p}=0,000)$.Conclusión: Por lo tanto, la investigación revela que la obesidad tiene un impacto negativo en la salud musculoesquelética, con resultados estadísticamente significativos para cambios posturales en rodilla y pie, artritis y columna vertebral y miembros inferiores.
\end{abstract}

Palabras clave: Obesidad; Metaanálisis; Dolor; Cambio postural.

\title{
1. Introduction
}

Obesity represents a global challenge due to the growing number of individuals with this disease (Aeseth, et al., 2019). Its incidence has increased in recent decades and obesity has become a major public health problem (Calenzani, et al., 2017).

Obesity is considered not only the oldest metabolic disorder, but also the most important nutritional disorder in developed countries presently. According to the 2015 World Health Organization (WHO) report, approximately $52 \%$ of the individuals aged 18 years and over are already overweight (Shan, et al., 2019).

The prevalence of obesity is equivalent a cross races and sexes, especially in the age group between 15 and 44 years. It is believed that $10 \%$ of the Brazilian population is overweight (Mello; Luft; Meyer, 2004).

In addition to the metabolic complications present in obesity, other orthopedic problems can also be observed, which are less studied (Brandelize \& Leite, 2010). However, the increase in the Body Mass Index (BMI) has been identified and considered as a risk factor for the presence of musculoskeletal symptoms (Onyemaechi, et al., 2016).

Disorders in the locomotor system can trigger not only pain, discomfort and postural changes, but also degenerative diseases, depending on the stage of bone maturation in which the individual is at (Enes \& Slater, 2010). Excess weight is the main cause for musculoskeletal discomfort, directly interfering with the structures responsible for joint movements (Rasia, et al., 2007).

These changes, evident in overweight individuals, can affect joint mobility, contributing to physical incapacities and reducing the quality of movements, and consequently generating a considerable economic burden for the health care system (Brach, et al., 2011; Lehnert, et al., 2013). It is noteworthy that musculoskeletal disorders are the main causes of disability and pain worldwide, especially in industrialized countries (Malik, et al., 2018).

Despite the limited scientific evidence available on this topic, the review of the scientific literature enables the observation of several changes in the musculoskeletal system at different stages of bone growth, demonstrating the importance of early therapeutic interventions based on lifestyle changes and physical activity (Batista, et al., 2003).

As the number of publications on this subject is limited, there is a need for scientific studies that address this topic. 


\section{Methods}

This study was a systematic review of the literature, conducted according to the Cochrane guidelines for the development of meta-analysis. The review procedures were guided by the Preferred Reporting Items for Systematic Review and Meta-Analyses (PRISMA) and the review protocol was registered in the International Prospective Register of Systematic Reviews (PROSPERO) under the reference number: CRD42018102078.

\subsection{Data Source and Search Strategies}

The search was conducted using Lilacs, Scielo, PubMed, Scopus and Web of Science electronic databases, from September 2017 to July 2018, updated in February 2020and the search strategies were defined by two researchers. The strategy PICO was used in this study. PICO represents an acronym for Patient, Intervention, Comparison and Outcome.

The National of Medicine publishes the Medical Subject Headings Sections (MeSH) in order to index articles in PubMed - MEDLINE. Bireme created DeCS (BIREME health sciences descriptors) from MeSH. The search headings used and combined were: "postural change", musculoskeletal disorders", orthopaedic alterations", obesity", “overweight” (Table 1).

Table 1. Descriptors and Boolean operators of search strategies.

\begin{tabular}{|c|c|}
\hline Data base & Search syntax \\
\hline Lilacs and Scielo & $\begin{array}{l}\text { ("postural dilorders" OR "alteração de postura" OR "musculoskeletal } \\
\text { disorders" OR "Musculoskeletal Diseases" OR "doenças muscoloesqueleticas" } \\
\text { OR "alterações ortopedicas" OR "orthopedic alterations" OR "orthopedic } \\
\text { change") AND (obesidade OR Obesity OR Overweight OR sobrepeso) }\end{array}$ \\
\hline PubMed & $\begin{array}{l}\text { ("musculoskeletal disorders"[All Fields] OR "Musculoskeletal Diseases"[All } \\
\text { Fields] OR "orthopedic alterations"[All Fields] OR "orthopedic change"[All } \\
\text { Fields]) AND (("obesity"[MeSH Terms] OR "obesity"[All Fields]) OR } \\
\text { ("overweight"[MeSH Terms] OR "overweight"[All Fields])) }\end{array}$ \\
\hline Scopus and Web of Science & $\begin{array}{l}\text { ("musculoskeletal disorders" OR "Musculoskeletal Diseases" OR "orthopedic } \\
\text { alterations" OR "orthopedic change") AND (Obesity OR Overweight) }\end{array}$ \\
\hline
\end{tabular}

Source: Authors (2021).

\subsection{Eligibility Criteria}

For the selection of articles, inclusion and exclusion criteria were established. The inclusion criteria were: a) studies with humans, without any restrictions for sample size, b) sample with a BMI greater than $30 \mathrm{Kg} / \mathrm{m} 2$ for adults and equal to or greater than the $85^{\text {th }}$ and $95^{\text {th }}$ percentile for age and sex respectively for children and adolescents, c) articles published in Portuguese, English and Spanish, d) articles with observational design, e) articles that used valid methods of assessment. The exclusion criteria were: a) duplicated articles, b) non-indexed articles, c) special populations, such as those with movement disorders or pain, d) meeting summaries, editorials, letter to the editor, and reviews. Functionality assessments of the locomotor system due to musculoskeletal disorders were beyond the scope of this review and were also not included.

\subsection{Study Selection}

In the first step selection, potential studies identified through the database search were inserted in the web-based systematic review software package "Covidence" (Veritas Health Innovation), which detected duplicate articles. After duplicates were excluded from the database, titles and abstracts were examined in order to identify potential articles for inclusion. In the second step, the full article text was examined for final inclusion/exclusion decision.

All stages of the selection process were conducted by two independent researchers (LMF/TK), and the few discrepancies were decided by consensus. 


\subsection{Data Extraction}

Data were extracted in a standardized manner, according to author and year of publication, type of study, journal where it was published, title, language and purpose of the study. The extraction continued identifying the sample size, and the predictor variables (age, gender, race, and mean BMI). Subsequently, the assessment methods and the outcomes were obtained.

\subsection{Quality Assessment and Evidence Synthesis}

The methodological quality of the included studies was analysed through STROBE - The Strengthening Reporting of Observational Studies in Epidemiology. A 22-item instrument, pertaining to title and abstract (item 1), introduction (items 2 and 3), methods (4 to 12), results (13 to 17), discussion (18 to 21) and other information on funding (item 22) (Elm, et al., 2017).

In order to assess study evidence, the adapted Levels of Evidence proposed by the Oxford Center for Evidence-Based Medicine was used. The Levels of Evidence are directly related to the research design, classifying and validating the study according to the focus: diagnostic, etiological, prognostic or therapeutic.

\subsection{Statistical Analysis}

The coefficient was conducted using Comprehensive Meta-Analysis 3.0 software. For the coefficient, the 95\% confidence interval odds ratio of each study were combined in order to estimate the effect of obesity on musculoskeletal disorders. The sample size and the occurrence of results were extracted from the data extraction form elaborated during this study.

The Mantel-Haenszel method was used. The technique assumes the effect of the randomized effect model, with a 95\% CI to perform the coefficient. Data heterogeneity was assessed using the inconsistency indicator. The Kappa coefficient was utilized in order to assess the interrater reliability.

\section{Results}

The database search identified a total of 5782 articles, of which 2012 were duplicates. The abstract titles of the remaining articles were independently selected by the two reviewers, including 789 articles that required a full-text screening. After screening, 16 observational articles that met the inclusion criteria were considered and included in this review, and seven were included in the meta-analysis (Figure 1).

The Kappa coefficient was (0,98, IC 95\%: 0,91; 1,0, p <0,001) for the screening title and abstract, and $(0,76$, IC $95 \%$ : $0,54 ; 0,98, \mathrm{p}<0,001)$ for the extraction process. No additional disagreements were found in the following stages. 
Figure 1. Flowchart of the study selection.
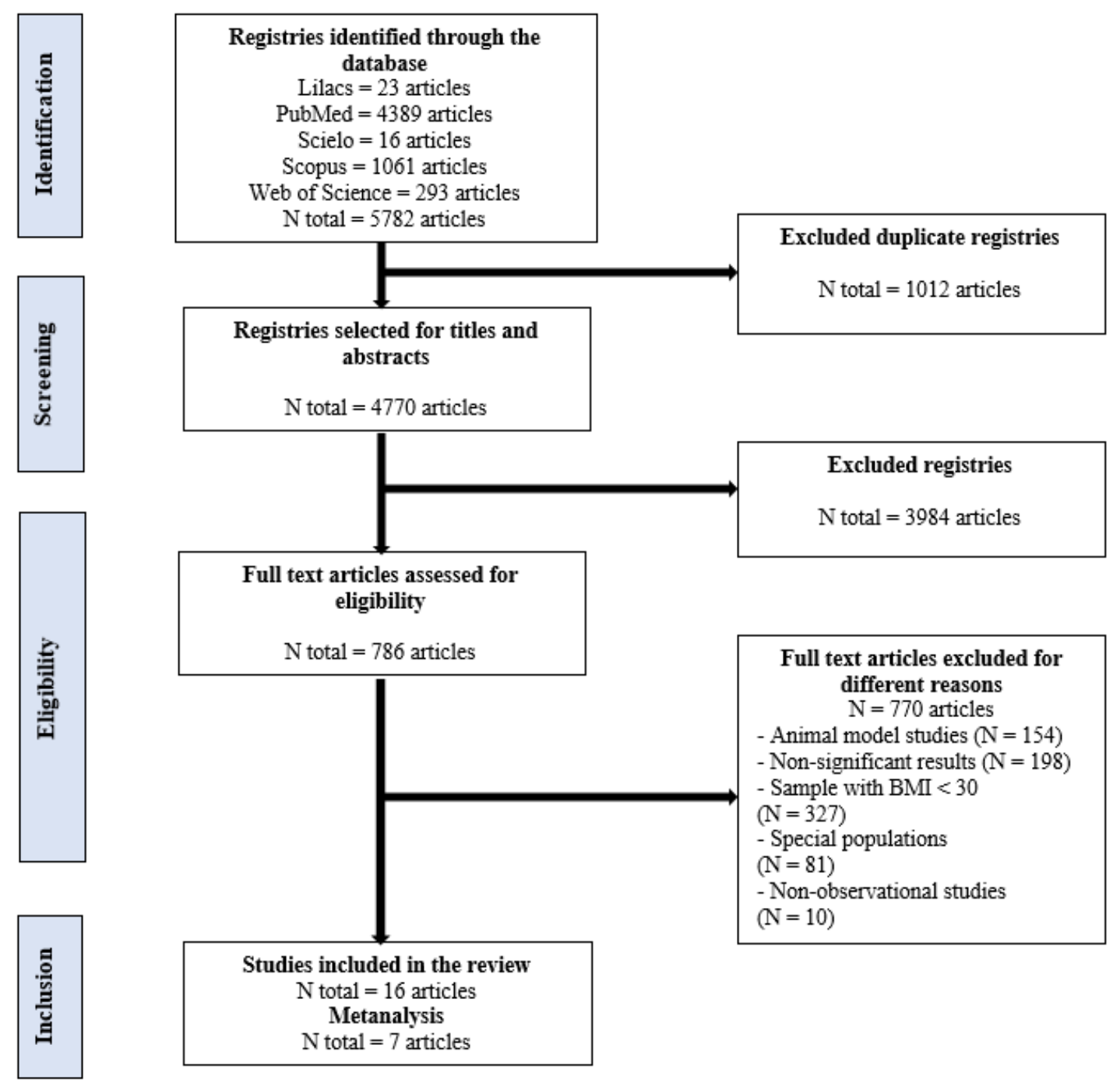

Source: Authors (2021).

\subsection{Main Characteristics of the Included Studies}

The articles were published between 2003 and 2016. Only one study (6,25\%) was published in Portuguese and the remaining ones were in English (93,75\%), all in indexed journals. Regarding the design of the included observational studies, $(n=13)$ were cross-sectional $(81,25 \%),(n=2)$ were case-control $(12,5 \%)$ and $(n=1)$ was a cohort $(6,25 \%)$ (Table 2$)$. 
Table 2. Main descriptive characteristics of the included studie.

\begin{tabular}{|c|c|c|c|c|}
\hline Author/Year & Design & Periodical/Journal & Variables studied & $\begin{array}{l}\text { Musculoskeletal disorders } \\
\text { observed }\end{array}$ \\
\hline $\begin{array}{l}\text { ACKERMAN E } \\
\text { OSBORNE, } 2012\end{array}$ & Cross-sectional & $\begin{array}{l}\text { BMC Musculoskeletal } \\
\text { Disorders }\end{array}$ & $\begin{array}{l}\text { Joint overloading in } \\
\text { obese people. }\end{array}$ & $\begin{array}{l}\text { Hip and knee pain, hip and knee } \\
\text { arthritis, and knee osteoarthritis. }\end{array}$ \\
\hline BRADY et al., 2015 & Cross-sectional & The Journal of Pain & $\begin{array}{l}\text { Body composition and } \\
\text { pain. }\end{array}$ & $\begin{array}{l}\text { Low back pain, hip and knee } \\
\text { pain. }\end{array}$ \\
\hline $\begin{array}{l}\text { BUTTERWORTH et al., } \\
2015\end{array}$ & Cross-sectional & Gait \& Posture & $\begin{array}{l}\text { Structure and pattern of } \\
\text { plantar loading in obese } \\
\text { people. }\end{array}$ & Flat feet. \\
\hline CASTRO et al., 2017 & Cross-sectional & FisioterapiaBrasil & $\begin{array}{l}\text { Orthopaedic changes in } \\
\text { obese children. }\end{array}$ & $\begin{array}{l}\text { Lumbar lordosis rectification, } \\
\text { valgus knees, and flat feet. }\end{array}$ \\
\hline CAZELANI et al., 2016 & Cross-sectional & Arch. Endocrinol. Metabol. & $\begin{array}{l}\text { Musculoskeletal } \\
\text { symptoms in obese } \\
\text { people. }\end{array}$ & $\begin{array}{l}\text { Ankle and foot pain, low back } \\
\text { pain, as well as knee, wrist, } \\
\text { hand and fingerpain. }\end{array}$ \\
\hline $\begin{array}{l}\text { FRILANDER et al., } \\
2016\end{array}$ & Cross-sectional & European Journal of Pain & $\begin{array}{l}\text { Overweight / obesity } \\
\text { and pain. }\end{array}$ & Knee pain. \\
\hline HOLMES et al., 2006 & Cross-sectional & Foot \& Ankle Specialist & $\begin{array}{l}\text { Achilles tendinopathy } \\
\text { and obesity. }\end{array}$ & Achilles tendinopathy. \\
\hline HULNES et al., 2003 & Cross-sectional & Scand. J Med Sci Sports & $\begin{array}{l}\text { Physical complaints } \\
\text { among normal weight, } \\
\text { obese and morbid obese } \\
\text { women. }\end{array}$ & $\begin{array}{l}\text { Knee and foot pain, low back } \\
\text { pain, hip osteoarthritis. }\end{array}$ \\
\hline KLEIN at al., 2013 & Case-control & Foot \& Ankle Specialist & $\begin{array}{l}\text { Role of Body Mass } \\
\text { Index (BMI) in the } \\
\text { development and } \\
\text { treatment of Achilles } \\
\text { tendinopathy. }\end{array}$ & Achilles tendinopathy. \\
\hline PINTO et al., 2003 & Cross-sectional & $\begin{array}{l}\text { Journal of Pediatrics and } \\
\text { Child. Health }\end{array}$ & $\begin{array}{l}\text { Osteoarticular changes } \\
\text { in obese children. }\end{array}$ & $\begin{array}{l}\text { Valgus knee, lumbar } \\
\text { hyperlordosis, low back pain } \\
\text { and pain in the lower limbs. }\end{array}$ \\
\hline SCOOT et al, 2013 & Cross-sectional & $\begin{array}{l}\text { BMC Musculoskeletal } \\
\text { Disorders }\end{array}$ & $\begin{array}{l}\text { Body Mass Index } \\
\text { (BMI) and Achilles } \\
\text { tendon pathology. }\end{array}$ & Achilles tendinopathy. \\
\hline SHIRI et al., 2008 & Cross-sectional & $\begin{array}{l}\text { American Journal of } \\
\text { Epidemiology }\end{array}$ & $\begin{array}{l}\text { Factors associated with } \\
\text { weight and prevalence } \\
\text { of low back pain. }\end{array}$ & Low back pain. \\
\hline SOUZA et al., 2005 & Case-control & Obesity Surgery & $\begin{array}{l}\text { Main postural changes } \\
\text { in obese people. }\end{array}$ & $\begin{array}{l}\text { Increased thoracic kyphosis, } \\
\text { lumbar hyperlordosisand thales } \\
\text { triangle, valgus knee and head } \\
\text { lateral anteversion }\end{array}$ \\
\hline THIEZE et al., 2017 & Cohort & Muscle \& Nerve & $\begin{array}{l}\text { Body Mass Index } \\
(\mathrm{BMI}) \text { and carpal tunnel } \\
\text { syndrome. }\end{array}$ & $\begin{array}{l}\text { The increase in BMI masked the } \\
\text { adjusted ratio eight times the } \\
\text { observed WR magnitude (square } \\
\text { and rectangular) and STC } \\
\text { among participants with normal } \\
\text { weight. }\end{array}$ \\
\hline ZHANG et al., 2017 & Cross-sectional & Osteoarthritis and Cartilage & $\begin{array}{l}\text { Factors associated with } \\
\text { higher degree of } \\
\text { meniscal body extrusion } \\
\text { in overweight and obese } \\
\text { women at high risk for } \\
\text { knee osteoarthritis } \\
\text { women. }\end{array}$ & $\begin{array}{l}\text { Extrusion of the medial } \\
\text { meniscus body. }\end{array}$ \\
\hline ZHU et al., 2016 & Cross-sectional & Biosci. Rep. & $\begin{array}{l}\text { Body Mass Index } \\
\text { (BMI) and fibrous } \\
\text { content of plantar } \\
\text { muscles. }\end{array}$ & $\begin{array}{l}\text { Increased fibrotic content of the } \\
\text { plantar and calf muscles. }\end{array}$ \\
\hline
\end{tabular}




\subsection{Musculoskeletal disorders in patients with obesity}

Seven studies were included in the meta-analysis. There was a statistically significant association between obesity and postural changes in the knee and foot, as well as pain in the spine and lower limbs.

The funnel plot for meta-analysis shows that obese individuals are 14 times more likely to have postural changes in the knee (OR 14.26, 95\% CI 4.98-40.80), I2 = 0\% ( $\mathrm{p}=0.000)$, 3 times more likely to develop postural changes in the foot (OR 3.20 , 95\% CI 2.08-4.94), $\mathrm{I} 2=0 \%(\mathrm{p}=0.000)$ and 3 times more likely to develop arthritis (OR 3.38, 95\% CI 0.72-1582), $\mathrm{I} 2=38.95 \%(\mathrm{p}=0.122)$.

Compared to eutrophic individuals, obese individuals are 5 times more likely to have pain in the lower limbs (OR 5.51 95\% CI 2.07-14.61), I2=81.02\% $(\mathrm{p}=0.001)$ and 9 times more likelyto have back pain (OR 9.78, 95\% CI 2.59-36.93), $\mathrm{I} 2=86.58 \%(\mathrm{p}=0.000)($ Figure 2$)$.

Figure 2.Musculoskeletal disorders in patients with obesity.

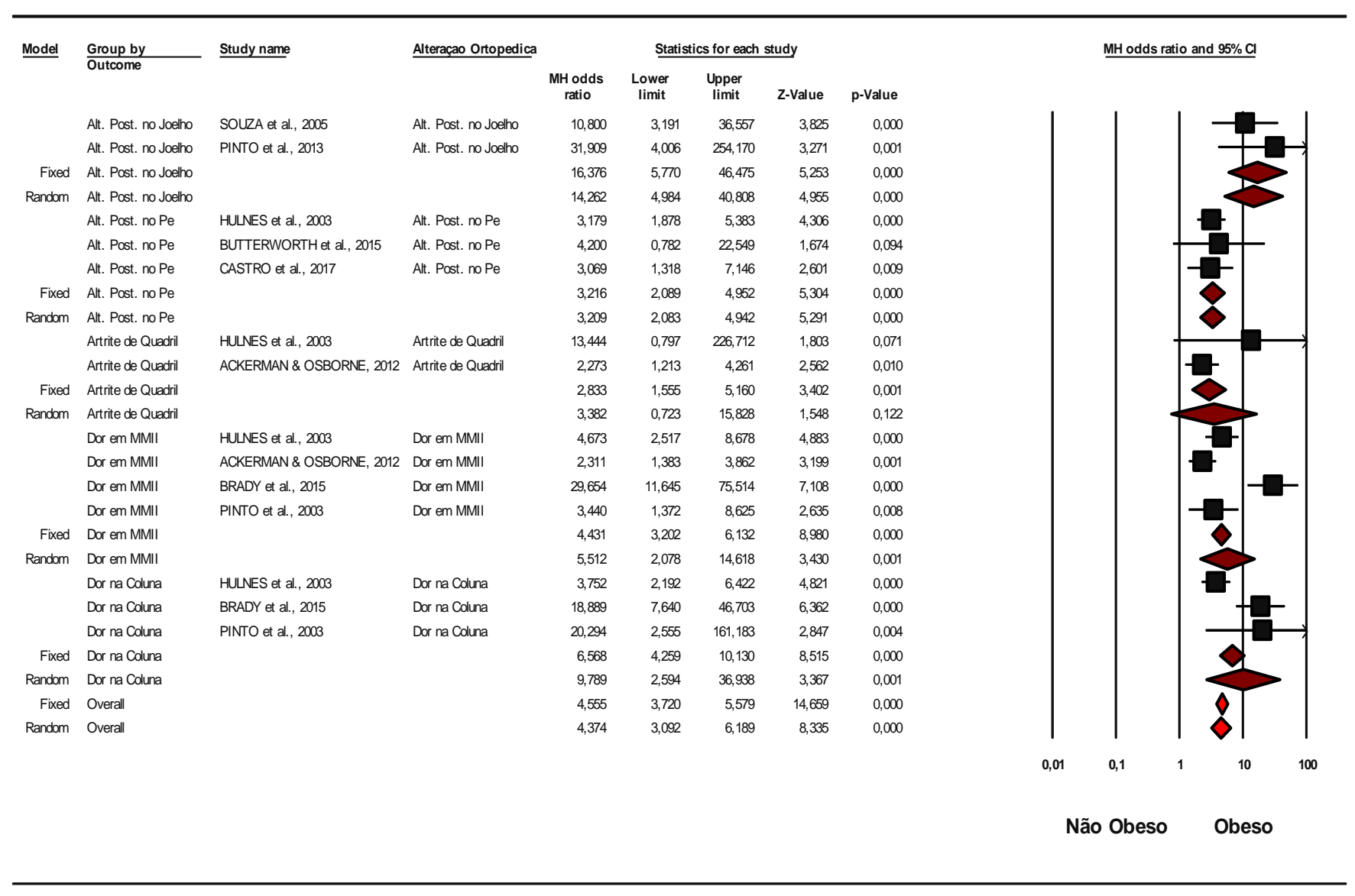

Source: Authors (2021).

\subsection{Methodological Quality Assessment and Evidence Synthesis}

Regarding methodological assessment, 4 studies (57, 14\%) obtained level A assessment ( $\geq 80 \%$ of the criteria proposed by STROBE), 3 studies (42,86\%), obtained level B assessment (79 a 50\% of the criteria proposed by STROBE).

As for level of evidence, 1 study presents moderate evidence (consistent level 2 or 3 studies or extrapolations from level 1 studies) and 6 studies $(85,1 \%)$ present weak evidence (level 4 or extrapolations from level 2 or 3 studies). 


\section{Discussion}

The purpose of this study was to examine the relationship between obesity and musculoskeletal disorders of the locomotor system. It was found that these changes manifest at different stages of bone maturation, in both sexes.

The association between these disorders and obesity is not yet clear. It is hypothesized that excess weight generates an overload which may interfere with bone remodelling, manifesting as deformities in the muscular and articular systems (Janini, et al., 2011).

One study observed that children with excess weight or obesity, regardless of the age group, report more musculoskeletal symptoms compared to normal weight children, and these changes commonly occur in the lower limbs, especially the ankle and the foot (Krul, el al., 2009).

Similarly, the prevalence of orthopaedic conditions in normal weight and overweight children was quantified using paediatric clinical records. Results showed that the most common self-reported joint complain in overweight children was knee pain, compared to the normal weight children (Taylor, et al., 2006).

Some studies show a higher prevalence of musculoskeletal pain in adolescents with obesity, especially in the lower limbs and lumbar spine compared to adolescents of normal weight (Stovitz, et al., 2008). Orthopedic changes was compared in overweight children and adolescents, as well as children and adolescents with obesity and found that this group has more genu valgum, recurvatum and quadriceps contracture compared to eutrophic children and adolescents (Janini et al., 2011).

Foot morphology of 2887 children between the ages of 2 and 14 years was compared. It was found that normal weight children have approximately equal distribution in all foot types for almost the entire childhood. Slender, robust and flat feet were more common in overweight children (Much, et al., 2008).

In the adult population with obesity, pain is more common in the lower limbs and the lumbar spine. One of the most common complaints reported among the adult population is chronic low back pain, leading to absence from work, decrease in physical function and disability (Malta, et al., 2017).

Similarly, another study examined the correlation between obesity and foot type among those with chronic heel pain in a sample of 33 men and 47 women. It was found that in the chronic heel pain group, BMI was higher and foot was more pronated compared to the group without chronic heel pain (Irving et al., 2007).

The relationship between obesity and foot pain in a sample of 136 individuals aged 25 to 62 years was investigated using the Manchester Foot Pain and Disability Index (MFPDI). Results showed that increasing BMI was associated with foot pain and disability (Vismara, et al., 2010).

Among the musculoskeletal changes that commonly occur in patients with obesity are spinal impairment, particularly disc degeneration and functional impairment of the joints (Adebipme, 2019).

A study examined the effect of obesity and low back pain on the spine, in a cross-sectional design including 13 individuals with obesity, 13 individuals with obesity and low back pain, and 11 healthy individuals. It was found that obesity was associated with reduced range of motion of the spine due to a reduced mobility at the pelvic and thoracic levels, and increased lumbar lordosis (Karlson et al., 2003). Overweight negatively affects common daily movements such as rising, lateral trunk inclination, lateral flexion, as well as walking (Bliddal, et al., 2016).

Risk factors for osteoarthritis, including age and obesity were examined. Results showed that higher body mass index and advanced age increased significantly the risk for total hip arthroplasty due to osteoarthritis (Tanamas et al., 2012).

It is important to detect these changes at an early age, thus children may be treated in a specialized manner, including the practice of guided physical activity. As a consequence, they may improve their pre-existing physical condition and may prevent future complications. Physical activity is considered an important primary prevention initiative to prevent obesity (Aaseath, et al., 2019). 


\section{Limitations of the Study}

Limitations of this study included the predictive characteristics of the sample, regarding mean BMI values, which provided results for obese samples. However, these values were not accredited according to the World Health Organization (WHO). Therefore, they were not eligible for inclusion, since this study compared results of obese samples with control groups comprised of overweight or eutrophic individuals. Several studies had a cross-sectional design, therefore results from this study are based on hypothesis, due to absence of longitudinal studies.

\section{Conclusion}

The research study showed that obesity has a negative impact on musculoskeletal health, with statistically significant results shown for postural changes in standing position, for the knees, arthritis and pain in the lower limbs and spine

\section{Conflict of Interest}

The authors declare that they have no conflict of interest.

\section{Acknowledgments}

To the Coordination for the Improvement of Higher Education Personnel (CAPES), for funding this research.

\section{References}

Aaseth J., Roer, G. E., Lien L., \& Bjorklund G. Is there a relationship between PTSD and complicated obesity? A review of the literature. Biomedicine \& Pharmacotherapy. 117(10):348-256.

Malik, K. M., Beckeriy, R., \& Imani, F. (2018) Musculoskeletal disorders a universal source of pain and disability misunderstood and mismanaged: A critical analysis Based on the U.S. model of care. Anesth Pain Medicine. 8(6):12132.

Castro, G G., Freitas, N. M., Barbosa, E. V. S., Amaral, L. C. R., Queiroz, F. L., \& Faria, K. C. (2017) Sobrepeso e obesidade infantil: fatores predisponentes para alterações ortopédicas. Fisioterapia Brasil. 18(4):426-432.

Adebimpe, W. O. Prevalence and knowledge of risk factors of childhood obesity among school-going children in Osogbo, south-western Nigeria. Malawi Medical Journal 31(1):19-24.

Berry, P. A., Wluka, A E., Davies-Tuck, M. L., Wang, Y., Strauss, B. J., Dixon, J. P., et al. (2010) The relationship between body composition and structural changes at the knee. Rheumatology. 49(12):2362-2369.

Bliddal, M., Pottega, A., Kirkegaard, H., Olsen, J., Jørgensen, J. S., Thorkild, I. A., et al. (2016) Association of Pre-Pregnancy Body Mass Index, PregnancyRelated Weight Changes, and Parity With the Risk of Developing Degenerative Musculoskeletal Conditions. Arthritis \& Rheumatology. 68(5):1156-1164.

Molina-Garcia, P, et al. (2019) A systematic review on biomechanical characteristics of walking in children and adolescents with overweight/obesity: Possible implications for the development of musculoskeletal disorders. Obesity Review. 20):1033-1044.

Moher, D, Liberati, A, Tetzlaff, J, \& Altman, D. G, PRISMA Group. Preferred reporting items for systematic reviews and meta-analyses: The PRISMA statement. PLoS Med. 6(7):1000097.

Elm, E, Altman, D. G, Eger, M, Pocock, S. J, Gotzasche, P. C., \& Vanderbroucke, J. P. (2017) The strengthening the reporting of observational studies in epidemiology (STROBE) statement: guidelines for reporting observational studies. The Lancet. 370(20):1453-1457

Nobre, M., \& Bernardo, W. (2006) Busca de evidência de fontes de informação científica, In: Nobre, M., Bernardo, W. Prática Clínica Baseada em Evidência. São Paulo. Elsevier, p.43-57.

Ackerman, I. R., \& Osborne, R. (2018) Obesity and increased burden of hip and knee joint disease in Australia: Results from a national survey. BMC Musculoskeletal Disorders. 254(13):1-13.

Brady, S. R. E., Bambino, B., Mamuaya, F. C., Anita, E., Wang, W. Y., Hussain, S. M., et al. (2015) Body composition is associated with multisite lower body musculoskeletal pain in a community-based study. The Journal of Pain. 16(8):700-706.

Butterworth, P. A., Urquhart, D. M., Landorf, K. B., Anita E, Wluka, D, Cicuttini, F. M., Menz, H. B. et al. Foot posture, range of motion and plantar pressure characteristics in obese and non-obese individuals. Gait\&Posture. 2015;41(8):465-469.

Castro, G. G., Freitas, N. M., Barbosa, E. V. S., Amaral, L. C. R., Queiroz, F. L., \& Faria, K. C. (2017) Sobrepeso e obesidade infantil: fatores predisponentes para alterações ortopédicas. Fisioterapia Brasil. 18(4):426-432. 
Calenzani, G., Santos, F. F., Wittmer, V. I., Freitas, G. K. F., \& Paro, F. M. Prevalence of musculoskeletal symptoms in obeses patientes candidates for bariatric sugery and its impact on health related quality of life. Arch, Endocrinol Metab. 2017;61(4):319-325.

Frilander H, Viikari-Juntura M, Heli€Ovaara P, Mutanen V. M, \& Mattila S. (2016) Obesity in early adulthood predicts knee pain and walking difficulties among men: A life course study. European Journal of Pain. 20(4):1278-1287.

Holmes G. B, \& Lin J. (2006) Etiologic Factors associated with symptomatic achilles tendinopathy. Foot \& Ankle International. 27(11):952-959.

Hulens M, Vansant G, Claessens A. L, Lusens R, \& Muls E. (2003) Predictors of 6-minute walk test results in lean, obese and morbidly obese women. Scandinavian Journal of Medicine e Science in Sports. 2016(13):98-105.

Klein E. E, Weil L. J, Weil L .S, \& Fleischer A. E. (2013) Body Mass Index and Achilles Tendonitis a 10-Year Retrospective Analysis. Foot \& Ankle International. 6(4):276278.

Pinto A. L. S, Holanda B, Radu A. S, Villares S. M, \& Lima F. R. (2006) Musculoskeletal findings in obese children. Journal of Pediatrics and Child Health. 42(6):341-344.

Scott R. T, Hyer C. F, \& Granata A. (2013) The correlation of achilles tendinopathy and body mass index. Foot \& Ankle Specialist. 6(4):283-285.

ShiriR, Juntura V. E., Varonen H., \& Heliovaara M. (2006) Prevalence and determinants of lateral and medial epicondylitis: a population study. American Journal of Epidemiology. 164(11):1065-1074.

Souza, A. S. F, Faintuch, J., Santanna, A. F., Rodrigues, G. J. J., Fonseca, B. I. C., \& Melo, R. D. (2005) postural changes in morbidly obese patients. Obesity Surgery. 15(7):1013-1016.

Thiese M. S, Merryweather A, Koric A, Ulrike O. T. T., Wood E. M., Apellusch J., et al. (2017) Association between wrist ratio and carpal tunnel syndrome: effect modification by body mass index. Muscle \& Nerve. 142(56):1047-1053.

Zhang F, Bierma-Zeinstra S. M, Ehg O, Turkiewicz A, Englund M, \& Runhaar J. (2017) Factors associated with meniscal body extrusion on knee MRI in overweight and obese women. Osteoarthritis and Cartilage. 25(5):694-699.

Zhu J, Zhang L, Choen Y, \& Zho J. Increased calf and plantar muscle fibrotic contents in obese subjects may cause ankle instability. Bioscience Reports. 2016;36(4):41-49.

Jannini S. N, Doria-Filho V., Damiani D., \& Silva C. A. A. (2011) Musculoskeletal pain in obese adolescents. Jornal de Pediatria. 87(4):329-335.

Krul M, Wouden J. C., Schellevis F. G., \& Koes B. W. (2009) Musculoskeletal problems in overweight and obese children. Annals of Family Medicine. 7(4):352-356.

Taylor E. D, Thiemi K. R, Mirch M. C, Ghorbanis S, Kraff T. M, Wailes A. D. C, et al. (2006) A. Orthopedic complications of overweight in children and adolescents. National Institutes of Health. 117(6):2167-2174.

Stovitz S. D, Pardee P. E, Vazquez-Beneditez G, \& Duval S. Musculoskeletal pain in obese children and adolescentes. Acta Pediatrica. 97(4):489-493.

Much M, Graus S, Krauss I, Maiwakd C, \& Horstmann T. (2008) Foot morphology of normal, underweight and overweight children. International Journal of Obesity. 32(7):1068-1075

Malta D. C, Oliveira D. C, Andrade S. S. C. A, Caiaffa W. T, Souza M. F. M, \& Bernal R. T. I. (2017) Factors associated with chronic back pain in adults in Brazil. Revista de Saúde Pública. 51(1):234-251.

Irving D. B, Cook J. L, YoNG M. A, \& Menz H. B. (2007) Obesity and pronated foot type may increase the risk of chronic plantar heel pain: a matched casecontrol study. BMC Musculoskeletal Disorders. 8(41):102-109.

Vismara L, Menegoni F, Zaina F, Gali M, NegrinI S, \& Capodagio P. (2010) Effect of obesity and low back pain on spinal mobility: a cross sectional study in women. Journal of Neuroengineering and Rehabilitation. 7(3):231-240.

Karlson E. W, Mandl L. A, Aneh G. N, Sangha O. S, Liang M. H, \& Grodstein F. (2003) Total Hip Replacement Due to Osteoarthritis: The Importance of Age, Obesity, and Other Modifiable Risk Factors. The American Journal of Medicine. 114:93-98.

Tanamas S, Wluka A. E, Berry H. B, Strauss B. J, Davies-Tuck M, Proietto J, et al. Relationship Between Obesity and Foot Pain and Its Association With Fat Mass, Fat Distribution, and Muscle Mass. Arthritis Care \& Research. (2012) 64(2):262-268. 